\title{
Production of 'Arbequina' olive tree seedlings under soilless growing systems
} Thaís Helena Cappellaro ${ }^{1}$, Márcia Wulff Schuch ${ }^{1}$, Luana Borges Affonso ${ }^{1}$, Geniane Lopes Carvalho Ozelame ${ }^{1}$,
Roberta Marins Nogueira Peil ${ }^{1}$ and Zeni Fonseca Pinto Tomaz ${ }^{1, *}$

${ }^{1}$ Universidade Federal de Pelotas, Programa de Pós Graduação em Agronomia, Fruticultura de Clima Temperado, Departamento de Fitotecnia, Caixa Postal 354, CEP 96010 900 Pelotas, RS, Brazil. Corresponding author, E-mail: zfptomaz@yahoo.com.br

\begin{abstract}
The The objective of this work was to evaluate 'Arbequina' olive tree seedlings growth obtained from mini-cuttings under soilless growth systems and different periods. The experimental design was entirely randomized according to the $3 \times 2 \times 5$ factorial design (three systems, two periods and five months of cultivation), with four replications of 12 plants. Under the hydroponic system, the experiment used sand as substrate and irrigated seedlings daily with a nutritive solution. For the Nutrient Film Technique (NFT), plants were irrigated using intermittent flow irrigation. Under the conventional system, plants were grown in plastic bags filled with the substrate Carolina ${ }^{\circledR}$, with $100 \mathrm{~mL}$ of nutritive solution every 15 days. The following variables were analyzed: number of shoots, number of secondary shoots and secondary shoots length during the cultivation period. After 150 days of cultivation, the following variables were analyzed: stem diameter, aerial part fresh and dry matter and root fresh and dry matter and root length for the conventional and semi-hydroponic systems. The use of the semi-hydroponic system promotes greater plant growth. The period with the highest temperature (spring/summer) promotes greater plant growth.
\end{abstract}

Key words: Hydroponic, growth period, Olea europaea.

\section{INTRODUCTION}

The 'Arbequina' olive tree is one of the most important in some countries, such as Spain, due to its vegetative vigor characteristics, earliness, olive oil high yield and good resistance to pest attacks and diseases (Oliveira et al., 2003). In Brazil, commercial cultivation of olive trees is a recent and expanding agricultural activity (Oliveira et al., 2009).

At the end of the twentieth century, the most adopted propagation method was the rooting of lignified minicuttings of about $60 \mathrm{~cm}$ long, placed directly in the planting holes. Then, growers started to root cuttings of about $20 \mathrm{~cm}$ kept in a nursery until seedlings development. Currently, the propagation of olive trees is carried out through the rooting of $12 \mathrm{~cm}$ long semi-lignified cuttings and two pairs of leaves under intermittent nebulization (Caballero and Rio Rincón 2006).

In the last couple of years, there were great advances in optimizing mini-cuttings rooting research (Goulart et al., 2008), making possible the commercial cloning of difficult to root genotypes and promoting increases in rooted mini-cuttings percentage (Alfenas et al., 2004) and number and length of roots (Schneck 1996 as cited in Wendling and Xavier 2005). This reflected positively on survival, initial start and plant performance in the field (Alfenas et al., 2004).

An important aspect to make the economic cultivation of olives in Brazil viable is the acquisition of quality seedlings (Oliveira et al., 2003). Although cuttings became the most disseminated technique for the propagation of olive trees (Oliveira 2001), the low rate of rooting and low quality of the root system are limiting factors (Alfenas et al., 2004). These limitations have been overcome by the mini-cutting technique used successfully in the propagation of several species such as forestry (Goulart et al., 2008; Souza et al., 2009) and fruit (Carvalho et al., 2007; Marinho et al., 2009) species.

After the adequate rooting of the cuttings, the last phase in olive multiplication is seedling collection for planting. Standard size is 80 to $100 \mathrm{~cm}$ of eight with one single main stem, starting the development of the plant's canopy with up to four branches or limbs. This condition occurs mainly in nurseries duly managed with irrigation, nutrients supply and the preventive control of pests and diseases (Oliveira et al.,2003,2009). Due to these needs, it is important to develop viable techniques for plant development, which are faster and cleaner.

In the conventional system, seedlings are kept in black polyethylene bags after rooting, reaching an ideal size and then transplanted to the field. However, this technique takes a year to develop a seedling. Thus, studies carried out with forestry species have analyzed seedlings growth in hydroponic systems to replace the conventional growing system.

The production of hydroponic seedlings is a new process with great use potential. As one of the advantages of the hydroponic systems in seedlings production are less seedlings production time, a more adequate supply of mineral nutrients, better conditions for seedling development and better control of pests and diseases plus protection against climate adversities offered by a protected environment.

In Brazil, the interest in hydroponics cultivation has grown in the last couple of years, especially the NFT (Nutrient Film Technique) or technique of the nutrients' laminar flow. Many of the hydroponics crops are not successful mainly due to lack of knowledge of the nutritional aspects of this production system, i.e., of the most adequate 
formulation and management of nutritious solutions. Other aspects that also interfere are related to the type of hydroponic growing system (Furlani 2008).

Among some soilless cultivation variations, the NFT-type hydroponics and the substrate cultivation stand out, being the most used. Under the NFT system, Fossati (1986) considers that the plant develops with $2 / 3$ of its root system submerged in nutritive solution, suppled to the plant in an intermittent flow from which it takes the nutrients, while the remaining portion of the root system develops in the open air to absorb oxygen. The nutritive solution is supplied to plants though channels that are also responsible for sustain the plants' root system. According to Furlani et al. (1999), in substrates cultivation, recipients filled with the material (substrates) are used to support plants, from where the nutritive solution is percolated and drained through. Andriolo et al. (1999) define substrate cultivation as being all the natural and artificial material, pure and mixed, which placed in a recipient, allows the fixation of the root system and works as plant support.

Practically, all vegetal species can be grown by hydroponics; however, the success of this technique depends on the correct choice of the type of system most adequate to the species to be grown.

Thus, the objective of this work was to evaluate the growth of 'Arbequina' olive seedlings collected through minicuttings under soilless cultivation systems, at different periods.

\section{MATERIALS AND METHODS}

The experiment was conducted in a plastic greenhouse at the Faculdade de Agronomia Eliseu Maciel Plant Science Department Didactics Field, Universidade Federal de Pelotas, located on the University Campus in the county of Capão do Leão, Rio Grande do Sul, during the following periods: March 12011 to August 2011 and November 22011 to April 2012.

Temperature and air relative humidity were monitored inside the greenhouse by a thermohygrograph of weekly registration, installed in a weather shelter at $1.5 \mathrm{~cm}$ above the floor.
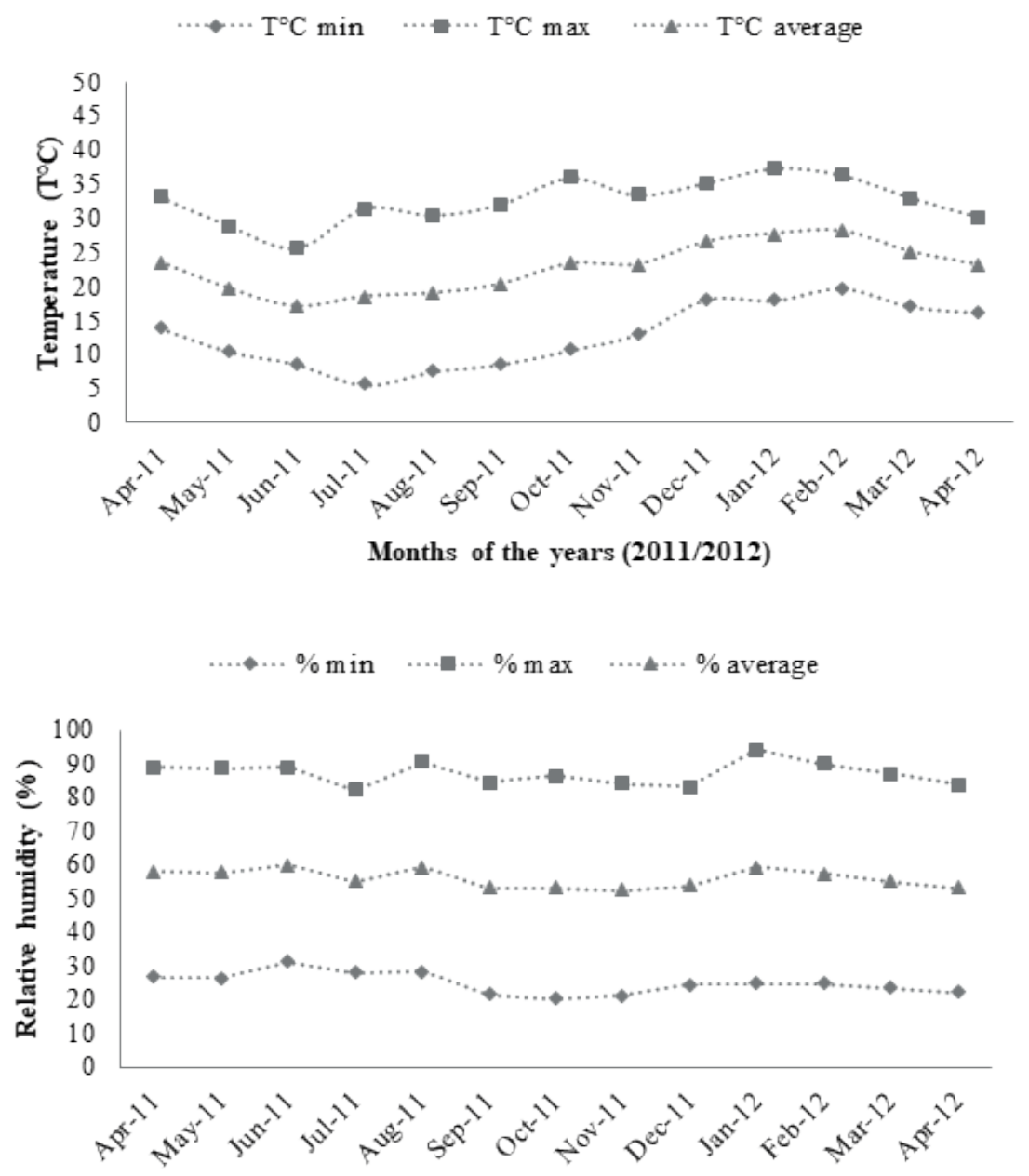

Months of years (2011/2012)

Figure 1. Temperature (A) and relative humidity (B) data for the months of April/2011 to April /2012, at the Pelotas Federal University, FAEM-UFPel Didactics Field, greenhouse, 2012. 
The experiment used 'Arbequina' olive tree seedlings originated from mini-cuttings propagation, rooted in $22 \mathrm{x} 14$ x $10 \mathrm{~cm}$ plastic boxes with vermiculite, and, 80 days later, were transplanted to the three systems.

For the development of the semi-hydroponics system (Figure 2), the experiment used flowerpots of $20 \mathrm{~cm}$ of height x 20 (larger base) +12 (smaller base) $\mathrm{cm}$ of width x $75 \mathrm{~cm}$ of length. The substrate used was sand of average granulometry. The bottom of the flowerpot contained a $5 \mathrm{~cm}$ layer of medium gravel to facilitate drainage. Flowerpots were placed on wood countertops of approximately $0.85 \mathrm{~cm}$ high. Inside the flowerpots, 12 seedlings were distributed in two lines 10x 10cm apart.

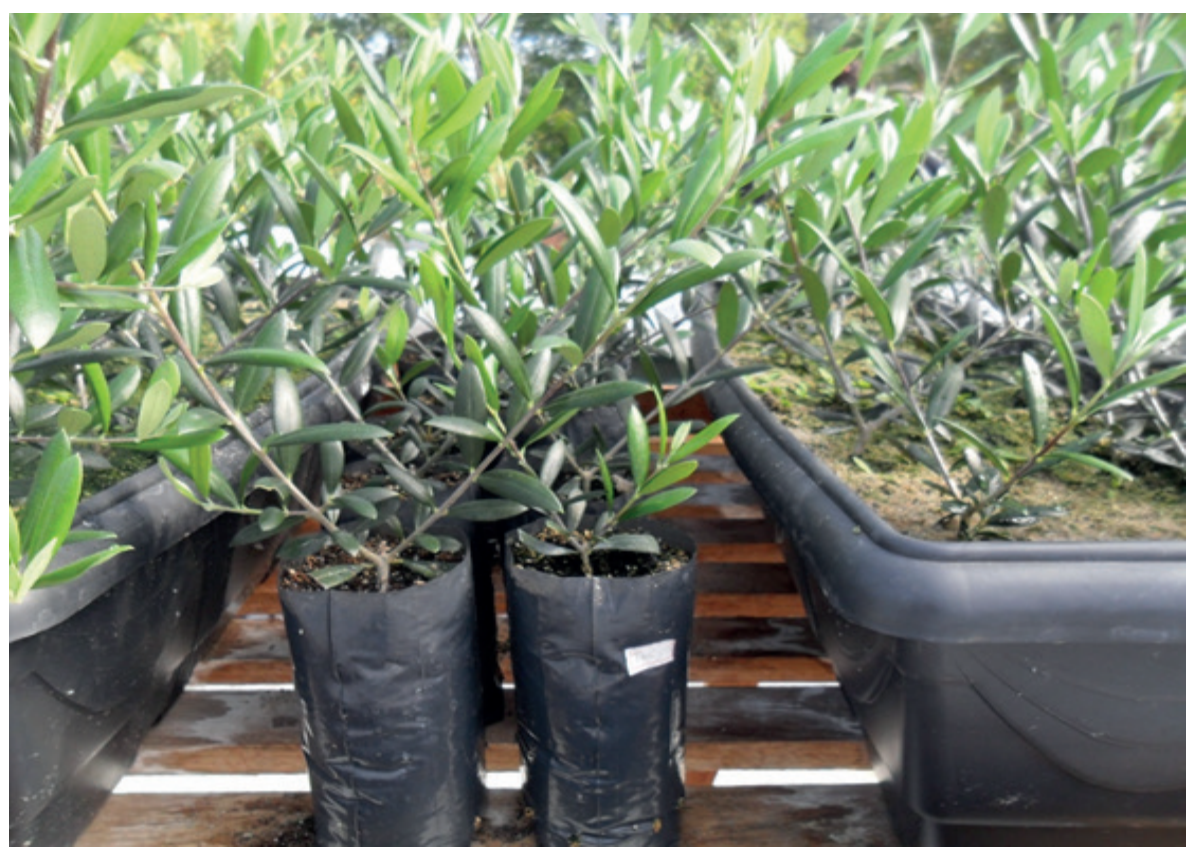

Figure 2. Semi-hydroponics and conventional systems. Pelotas, FAEM-UFPel, 2012.

The flowerpots were irrigated with nutritive solution, an average of $1 \mathrm{~L}$ per day, depending on the weather conditions. The solution was formulated according to the crop needs, being monitored by electrical conductivity measures (using a digital electro conductive meter) and $\mathrm{pH}$ (using a digital $\mathrm{pH}$ meter). Every 15 days, the sand in the flowerpots was washed with rainwater to prevent salinization.

To assemble the NFT system (Figure 3), the study used a cultivation top made with fiber cement tiles 3.66 by 1.10 and $6.0 \mathrm{~mm}$ of thickness, with six $5.0 \mathrm{~cm}$ deep channels. The top was placed on wood easels $0.85 \mathrm{~m}$ high and, with a gap of $2.0 \%$ for the nutritive solution to flow until the fiberglass storage tank $(250 \mathrm{~L})$. Then, it was covered with a double-face, black - and - white plastic (150 $\mu \mathrm{m}$ thick), perforated to place the seedlings. In the NFT system, spacing between plants was $10 \mathrm{~cm}$ in the cultivation channels and $18 \mathrm{~cm}$ between the lines (channels).

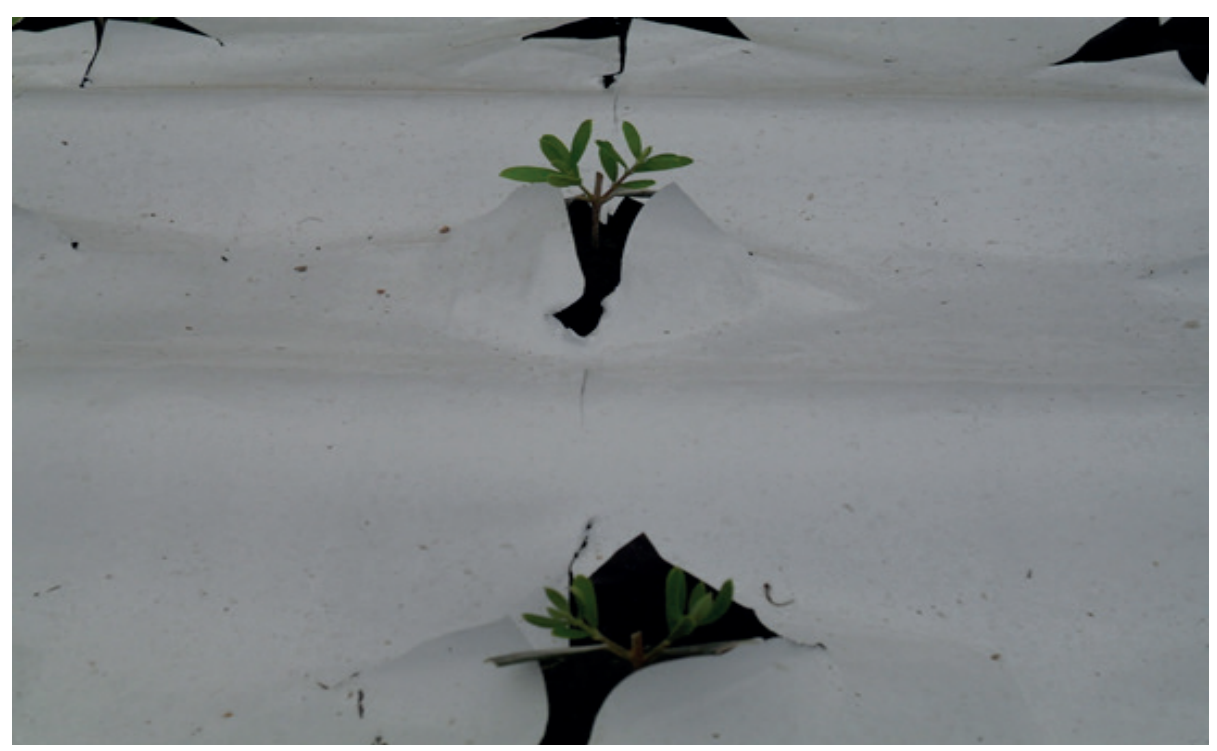

Figure 3. Nutrient Film Technique (NFT) system. Pelotas, FAEM-UFPel, 2012. 
Plants were irrigated through intermittent flow irrigation programmed by a timer responsible for turning on and off the motor pumps of the cultivation tops at pre-established time intervals, according to the needs of the crop.

In the conventional system (Figure 2), plants were grown in black plastic bags $\left(10 \times 20 \mathrm{~cm}\right.$ ) filled with $1.5 \mathrm{dcm}^{3}$ of Carolina ${ }^{\circledR}$ commercial substrate, receiving nutritive solution every 15 days. According to the plants' needs, the little bags were irrigated daily with rainwater. In the conventional system, plants were distributed individually in planting bags with spacing of $10 \times 10 \mathrm{~cm}$.

The nutritive solution used in the systems was formulated according to the needs of olive crops by Schuch and Peil (2012), with the following composition of macronutrients (in mmol L-1): 14.4 of NO3-, 1.0 of H2PO4-, 2.8 of SO42-, 1.1 of $\mathrm{NH} 4+, 3.3$ of $\mathrm{K}+, 5.5$ of Ca2+ and 2.8 of $\mathrm{Mg} 2+$; and of micronutrients (in mg L-1): 1.7 of Fe, 0.5 of $\mathrm{Mn}, 0.3$ of $\mathrm{Zn}, 0.1$ of $\mathrm{Cu}, 0.5$ of $\mathrm{B}$ and 0.1 of Mo. For the preparation of the nutritive solution, Rainwater and the following fertilizers and products were used: calcium nitrate, ammonium nitrate, monopotassium phosphate, potassium phosphate, magnesium sulfate, ammonium sulfate, boric acid, copper sulfate, iron sulfate, Na-EDTA, manganese sulfate, zinc sulfate and sodium molybdate. The $\mathrm{pH}$ was kept between 6.5 and 7.5 and the electrical conductivity (EC) was $2,1 \mathrm{dS} \mathrm{m}-1$.

The experimental design was totally randomized, with $3 \times 2 \times 5$ factorial (systems $\times$ periods $\times$ cultivation months) with 4 replications of 12 plants.

The following variables were analyzed: number of shoots, shoot length, number of secondary shoots and secondary shoots length. After 150 days of cultivation, the following variables were analyzed: stem diameter, aerial part fresh and dry matter, root fresh and dry matter and root length for the conventional and semi-hydroponic system.

An analysis of variance was conducted and means were submitted to a polynomial regression analysis. Number of roots data were transformed in a square root of $x+0.5$ for number of roots, using the statistical program Winstat, version1.0 (Machado and Conceição 2003).

\section{RESULTS AND DISCUSSION}

There was an interaction among system $\mathrm{x}$ period $\mathrm{x}$ cultivation days for shoots height, number of secondary shoots and secondary shoots height variables. The period 2 variable (spring/summer) showed the best results for all variables. For the number of shoots variable, only period was significant. As for the plant stem, aerial part fresh and dry matter and root fresh and dry matter variables, there was interaction between systems and periods and for the shoots diameter variable, there was only significance for the system and period factors. The analysis of variance showed an interaction between the system (conventional and semi-hydroponic) x period factors for the root length variable.

In regards to the shoots height variable, the periods showed significant differences for days of cultivation and systems used. With the increase in cultivation days, shoots height increased regardless of the cultivation system used for period 1 (autumn/winter) (Figure 4A). As for period 2 (spring/summer), with the increase in cultivation days there was an increase in shoots height, and at 120 and 150 days of cultivation, the semi-hydroponic system showed greater shoots height of 43.51 and $76.16 \mathrm{~cm}$ respectively (Figure 4B).

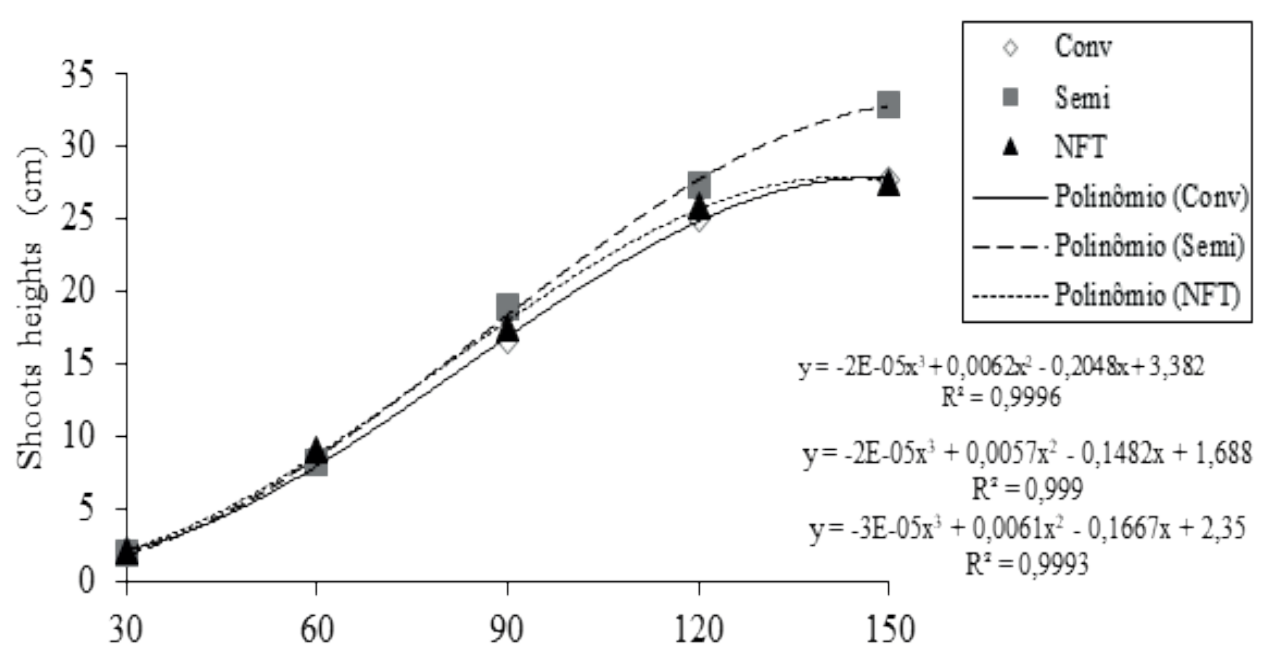

Days of cultivation 


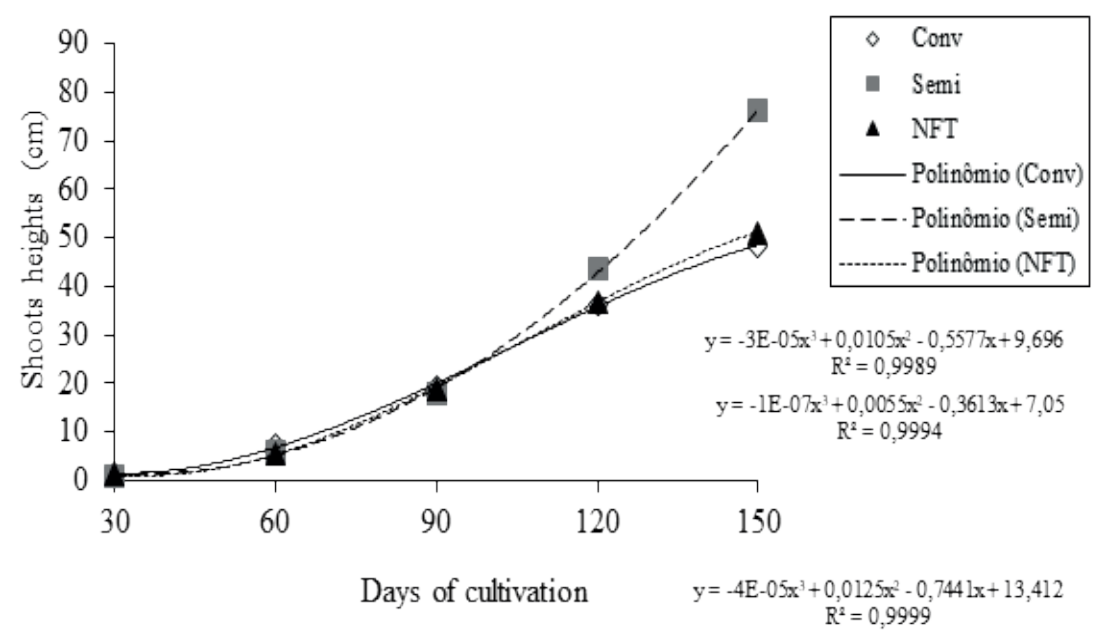

Figure 4. Shoots heights $(\mathrm{cm})$ in function of days of cultivation and systems (conventional and semi-hydroponic and NFT) at period 1 ( autumn / winter) (A) and period 2 (spring/summer) (B) in the growth of olive tree mini-cuttings, Arbequina cultivar. Pelotas, FAEM-UFPel, 2012.

In regards to number of secondary shoots, the periods showed significant differences for the cultivation days and systems used. With the increase in cultivation days, the number of secondary shoots increased, and at 120 and 150 days of cultivation, the semi-hydroponic system sowed greater number of secondary shoots of 10.14 and $10.28 \mathrm{~cm}$ respectively (Figure 5A). For period 1 ( autumn/winter) and period 2 (spring/summer), at 60-120 days of cultivation, the semi-hydroponic and NFT systems showed greater number of secondary shoots and at 150 days, the hydroponic system was superior to the others (Figure 5B).
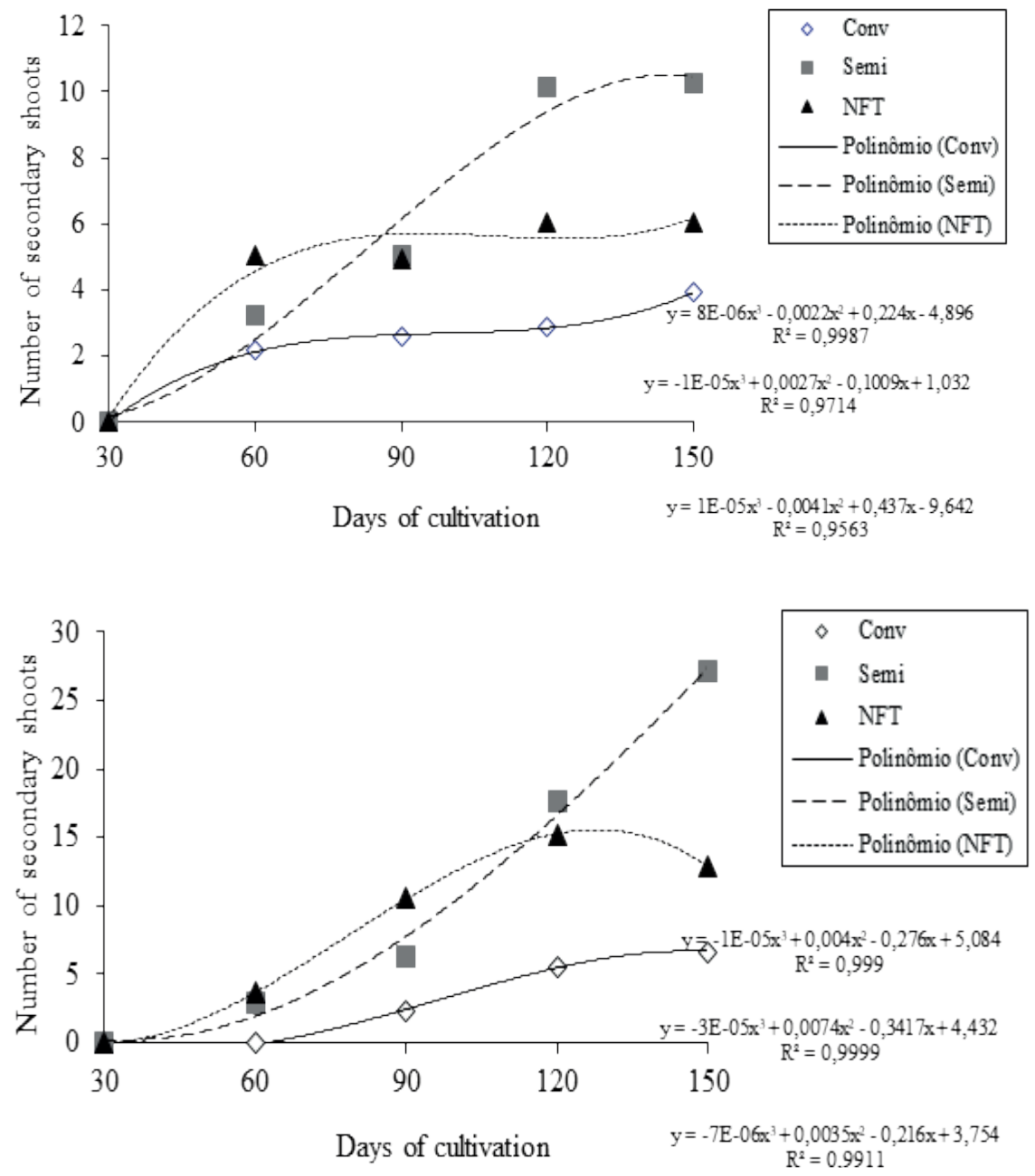

Figure 5. Number of secondary shoots in function of cultivation days and systems (conventional, semi-hydroponic and NFT) at period 1 (autumn/winter) (A) and period 2 (spring/summer) (B) in the growth of olive tree mini-cuttings, Arbequina cultivar. Pelotas, FAEMUFPel, 2012. 
For secondary shoots height, the periods showed significant differences for days of cultivation and systems used, with the increase in days of cultivation, with the increase in cultivation days secondary shoots height increased regardless of the cultivation system adopted for period 1 (Figure 6A) and for period 2 at 120 days the NFT system showed greater height $(8.27 \mathrm{~cm})$ and at 150 days, the NFT and semi-hydroponic systems showed greater secondary shoots heights, 16.31 and $16.05 \mathrm{~cm}$ respectively (Figure 6B).
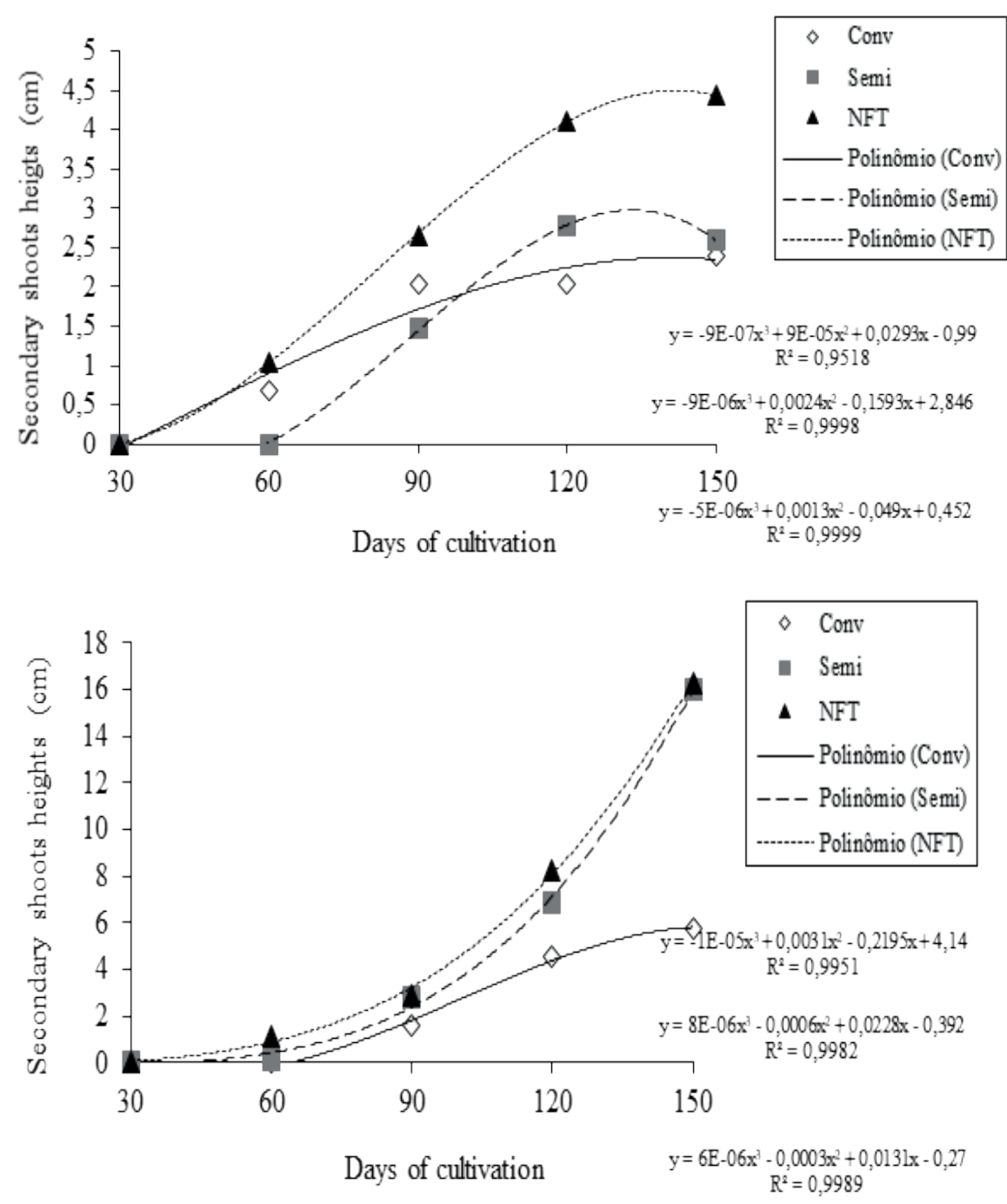

Figure 6. Secondary shoots height in function of cultivation days and systems (conventional, semi-hydroponic and NFT) at period 1 (autumn/winter) (A) and period 2 (spring/summer) (B) in the growth of olive tree mini-cuttings, Arbequina cultivar. Pelotas, FAEM-UFPel, 2012.

Tomaz et al. (2014), using the semi-hydroponic system for the development of peach rootstocks, obtained height of $105 \mathrm{~cm}$ in 190 days, compared to traditional rootstock development methods. However, for the araçá (Psidium cattleyanum, according to the same authors, observed that the semi-hydroponic system showed no difference form the conventional system.

When testing blueberry (Vaccinium ashei) seedlings under the semi-hydroponic system, Nascimento et al. (2011a), recorded the best results for aerial part height and number of shoots. These results can be visualized in the present work. Cunha et al. (2008) also obtained better results with the hydroponic system in relation to the conventional system, working with Brazilian coral tree (Erythrina sp) mini-cuttings (Erythrina sp), obtaining greater height and neck diameter.

For the number of shoots variable, only period showed significant difference, being period 1 with the greatest number of shoots (1.84).

In regards to stem diameter and aerial fresh matter for periods 1 and 2, the semi-hydroponic stem showed greater diameter and matter (Table 1).

For the aerial dry matter variable, root fresh and dry matter, the conventional, semi-hydroponic and NFT systems for period showed no differences; however, for period 2, the semi-hydroponic system showed greater matter (Table 1). 
Table 1. Means for stem diameter $(\mathrm{mm})$, aerial part fresh matter $(\mathrm{g})$, aerial part dry matter $(\mathrm{g})$, root fresh matter $(\mathrm{g})$, root dry matter $(\mathrm{g})$ and root length $(\mathrm{cm})$ under different periods and cultivation systems of the 'Arbequina' olive tree. UFPEL/FAEM - Pelotas, 2012.

\begin{tabular}{|c|c|c|c|}
\hline \multirow[t]{2}{*}{ Period } & Conventional & Semi-hydroponic & NFT \\
\hline & \multicolumn{3}{|c|}{ Stem diameter $(\mathrm{mm})$} \\
\hline 1(autumn/winter) & $4.7 \mathrm{Bb}^{1}$ & $6.42 \mathrm{Ab}$ & $5.65 \mathrm{ABb}$ \\
\hline \multirow[t]{2}{*}{2 (spring/summer) } & $6.35 \mathrm{Ca}$ & $9.69 \mathrm{Aa}$ & $7.49 \mathrm{Ba}$ \\
\hline & \multicolumn{3}{|c|}{$\operatorname{APFM}(\mathrm{g})$} \\
\hline 1(autumn/winter) & $13.69 \mathrm{Bb}$ & $25.37 \mathrm{Ab}$ & $21.13 \mathrm{ABb}$ \\
\hline \multirow[t]{2}{*}{ 2(spring/summer) } & $26.44 \mathrm{Ca}$ & $121.21 \mathrm{Aa}$ & $41.57 \mathrm{Ba}$ \\
\hline & \multicolumn{3}{|c|}{ APDM (g) } \\
\hline 1(autumn/winter) & $6.37 \mathrm{Bb}$ & $11.83 \mathrm{Ab}$ & $10.42 \mathrm{ABb}$ \\
\hline \multirow[t]{2}{*}{ 2(spring/summer) } & $12.23 \mathrm{Ca}$ & $51.73 \mathrm{Aa}$ & $19.11 \mathrm{Ba}$ \\
\hline & \multicolumn{3}{|c|}{ RFM (g) } \\
\hline 1(autumn/winter) & $5.17 \mathrm{Ab}$ & $7.25 \mathrm{Ab}$ & $4.90 \mathrm{Ab}$ \\
\hline \multirow[t]{2}{*}{ 2(spring/summer) } & $12.03 \mathrm{Ca}$ & $42.25 \mathrm{Aa}$ & $31.20 \mathrm{Ba}$ \\
\hline & \multicolumn{3}{|c|}{ RDM (g) } \\
\hline 1(autumn/winter) & $1.28 \mathrm{Aa}$ & $2.33 \mathrm{Ab}$ & $3.43 \mathrm{Ab}$ \\
\hline \multirow[t]{2}{*}{2 (spring/summer) } & $3.78 \mathrm{Ba}$ & $12.41 \mathrm{Aa}$ & $7.67 \mathrm{Ba}$ \\
\hline & \multicolumn{3}{|c|}{ Root length $(\mathrm{cm})$} \\
\hline 1(autumn/winter) & $20.96 \mathrm{Aa}$ & $19.22 \mathrm{Ab}$ & \\
\hline 2(spring/summer) & $16.65 \mathrm{Bb}$ & $26.01 \mathrm{Aa}$ & \\
\hline
\end{tabular}

${ }^{1}$ Uppercase letters in the line and lowercase in the column do not differ statistically among them by the Tukey test at $5 \%$ of probability.

When testing the conventional and semi-hydroponic systems, Nascimento et al. (2011b) obtained higher minicutting root fresh and dry matter content means than the conventional system. During period, the conventional and semi-hydroponic systems showed no differences regarding root length; however, during period 2, the semihydroponic system showed greater length $(26.1 \mathrm{~cm})$ (Table 1$)$.

The supply of nutritive solution in the hydroponic system provides better nutrients availability and, consequently, promotes greater seedlings vegetative growth. In the present work, the period of the year was an important factor for plant growth, being period 2, which corresponds to the months of November to March, the period that brought the best results. This may occur since, during this period, temperatures are higher, promoting, together with the availability of nutrients through the provision of a nutritive solution, greater plant growth.

During warmer periods, the increase in photosynthesis rate may contribute to plant growth. The stomata is an epidermal structure that controls the input and output of plant gases. The opening of stomata depends on several factors such as luminosity, carbon gas concentration and water availability. Thus, under ideal temperature and atmospheric carbon gas concentration, the photosynthesis rate increases progressively due to the increase in luminosity. (Amabis and Martho 2001).

\section{CONCLUSION}

The adoption of the semi-hydroponic system during the spring/summer period promotes greater 'Aberquina' olive tree plant's growth.

\section{ACKNOWLEDGEMENT}

To CAPES for granting of the PhD scholarship and Universidade Federal de Pelotas for making the material and facilities available for the development of this work.

\section{REFERENCES}

Alfenas AC, Zauza EAV, Mafia RG and Assis TF (2004) Clonagem e doenças do eucalipto. UFV: Viçosa, 442p.

Andriolo JL, Duarte TS, Ludke L and Skrebsky EC (1999) Caracterização e avaliação de substratos para o cultivo do tomateiro fora do solo. Horticultura Brasileira 17(3): 215-219.

Amabis JM and Martho GR (2001) Conceitos de biologia: origem da vida, citologia, histologia e embriologia. Ed. Moderna, São Paulo, 222p. 
Caballero JM and Rio Rincón C (2006) Propagação da oliveira por enraizamento de estacas semilenhosas sob nebulização. Informe Agropecuário 27(231): 33-38.

Carvalho RIN, Silva ID and Faquim R (2007) Enraizamento de miniestacas herbáceas de maracujazeiro amarelo. Semina: Ciências Agrárias 28(3): 387-392.

Cunha ACM, Wendling I and Souza Junior L (2008) Miniestaquia em sistema de hidroponia e em tubetes de corticeira-do-mato. Ciência Florestal 18(1): 85-92.

Fossati C (1986) Como praticar el hidrocultivo. Edaf, Madrid, 174p.

Furlani PRF, Silveira LCP, Bolonhezi D and Faquin V (1999) Estruturas para o cultivo hidropônico. Informe Agropecuário 20(200-1): 72-80.

Furlani PR (2008) Principais sistemas hidropônicos em operação no Brasil. In: IV Simpósio: Pythium em sistemas hidropônicos - danos e perspectivas para o controle, XXXI Congresso do Grupo Paulista de Fitopatologia, CampinasSP.

Goulart PB, Xavier A and Cardoso NZ (2008) Efeito dos reguladores de crescimento AIB e ANA no enraizamento de miniestacas de clones de Eucalyptus grandis X Eucalyptus urophylla. Revista Árvore 32(6): 1051-1058.

Machado AA and Conceição AR (2003) Sistema de análise estatística para Windows. WinStat. Versão 1.0. UFPel. Marinho CS, Milhem LMA, Altoé JA, Barroso DG and Pommer CV (2009) Propagação da goiabeira por miniestaquia. Revista Brasileira de Fruticultura 31(2): 607-611.

Nascimento DC, Schuch MW and Peil RMN (2011a) Enraizamento de microestacas de mirtileiro provenientes de microjardim clonal semi-hidropônico. Revista Brasileira de Fruticultura 33(4): 1251-1256.

Nascimento DC, Schuch MW and Peil RMN (2011b) Crescimento e conteúdo de nutrientes minerais em mudas de mirtileiro em sistema convencional e semi-hidropônico. Revista Brasileira de Fruticultura 33(4): 1155-1161.

Oliveira AF (2001) Enraizamento de estacas semilenhosas e cultura de embriões in vitro de oliveira (Olea europaea L.). Tese, Doutorado em Agronomia/Fitotecnia, Universidade Federal de Lavras.

Oliveira AF, Pasqual M, Chalfun NNJ, Albuquerque RM and Rio Rincón C (2003) Influência do número de nós em estacas semilenhosas de oliveira (Olea europaea L.) no enraizamento sob câmara de nebulização. Ciência e Agrotecnologia, 27(2): 332-338.

Oliveira AF, Neto JV, Gonçalves ED and Mesquita HA (2009) Pioneirismo marca pesquisa sobre oliveira em Minas Gerais. Informe Agropecuário 30(n. esp.): 109-117.

Schuch MW and Peil RMN (2012) Soilless cultivation systems: A new approach in fruit plants propagation in the south of Brazil. Acta Horticulturae 952: 877-883.

Souza JCAV, Barroso DG, Carneiro JGA, Teixeira SL and Balbinoti E (2009) Propagação vegetativa de cedroaustraliano (Toona ciliata M. Roemer) por miniestaquia. Revista Árvore 33(2): 205-213.

Tomaz ZFP, Schuch MW, Peil RMN and Timm CRF (2014) Desenvolvimento de porta -enxertos de pessegueiro obtidos de miniestacas, em duas épocas, e sistema de cultivo sem solo Revista Brasileira de Fruticultura 36(4): 988995.

Wendling I and Xavier A (2005) Influência da miniestaquia seriada no vigor radicular de clones de Eucalyptus grandis. Revista Árvore 29(5): 681-689.

Received: March 30, 2017. 